\title{
PENDEKATAN DAN POLITIK HUKUM DALAM PEMBANGUNAN HUKUM PIDANA DI INDONESIA
}

\author{
Any Ismayawati \\ Institut Agama Islam Negeri Kudus \\ E-mail : any.ismayawati@yahoo.com
}

\begin{abstract}
The construction of the law is a sustainable development, because the formation of the law was never completed. This is because the law develops as the community develops. In carrying out legal development there must be a determinant of the direction, the direction of legal development, as well as the development of criminal law in Indonesia. Based on this, it will be examined how the politics of criminal law development law in Indonesia, as well as how the approach used in order to create substantive justice. To achieve this goal is used qualitative research type with normative juridical approach. To obtain the data used historical, philosophical and hermeneutic approach. The results of this study show that the politics of law that is the direction of criminal law development in order to create substantive justice is the politics of law based on Pancasila, while the approach used is a religious approach, scientific approach, policy approach and humanist approach.
\end{abstract}

Keywords: Legal Politics, Legal Approach, Criminal Law Development

\begin{abstract}
Abstrak
Pembangunan hukum merupakan pembangunan yang berkelanjutan, karena pembentukan hukum itu tidak pernah selesai. Hal tersebut dikarenakan hukum berkembang seiring perkembangan masyarakat yang bersangkutan. Dalam melakukan pembangunan hukum harus ada penentu arah, ke mana arah pembangunan hukum, demikian juga halnya dalam pembangunan hukum pidana di Indonesia. Berdasarkan hal tersebut maka tulisan bertujuan untuk mengkaji bagaimana politik hukum pembangunan hukum pidana di Indonesia, serta bagaimana pendekatan yang digunakan agar dapat menciptakan keadilan substantif. Untuk mencapai tujuan tersebut digunakan jenis penelitian kualitatif dengan pendekatan yuridis normatif. Untuk mendapatkan data digunakan pendekatan historis, filosofis dan hermeneutik. Hasil penelitian ini menunjukkan bahwa politik hukum yang menjadi arah pembangunan hukum pidana agar tercipta keadilan substantif adalah politik hukum berdasarkan Pancasila. Sedangkan pendekatan yang digunakan agar dapat terwujud keadilan substantif dalam pembangunan hukum adalah pendekatan religius, pendekatan keilmuan, pendekatan kebijakan dan pendekatan humanis.
\end{abstract}

Kata Kunci : Politik Hukum, Pendekatan Hukum, Pembangunan Hukum Pidana 


\section{PENDAHULUAN}

Pembangunan hukum pidana di Indonesia berjalan seiring dengan perkembangan masyarakat dan perkembangan kebutuhan dalam menyelenggarakan kehidupan berbangsa dan bernegara. Sejak Indonesia merdeka sampai saat ini sudah banyak regulasi di bidang hukum pidana yang ditetapkan untuk memenuhi kebutuhan dan kekosongan hukum pidana dengan tujuan agar tewujudnya ketertiban dan kesejahteraan masyarakat sebagaimana tujuan hukum pada umumnya. Pembangunan hukum pidana masih terus berlangsung, karena sejatinya pembangunan hukum tidak pernah selesai sebagaimana keberlangsungan negara itu sendiri.

Menurut Barda Nawawi Arief pembangunan hukum pidana pada hakikatnya pembaharuan hukum pidana yang mengandung makna, suatu upaya untuk melakukan reorientasi dan reformasi hukum pidana yang melandasi kebijakansosial, kebijakan kriminal dan kebijakan penegakan hukum di Indonesia (Maulidah \& Jaya, 2019).

Pembangunan hukum pidana merupakan suatu keniscayaan yang harus dilakukan dalam kerangka pembangunan hukum nasional. Hal tersebut dikarenakan masih banyak hukum pidana di Indonesia yang menggunakan hukum kolonial. Sejak negara ini diproklamasikan, hukum pidana bangsa Indonesia bersumber pada Kitan Undang-Undang Hukum Pidana yang selanjutnya disebut KUHP adalah warisan dari penjajah Belanda. KUHP tersebut merupakan produk pemerintah kolonial Belanda, dengan berdasarkan pada titik pandang bangsa Belanda yang individualistik dan liberalistik, sehingga asas-asas hukum yang terkandung dalam KUHP juga merupakan perwujudan dari pandangan hidup bangsa Belanda, yang sangat berbeda dengan jiwa dan nilai bangsa Indonesia. Oleh sebab itu, pembangunan hukum pidana Indonesia harus dilakukan berdasarkan pada nilai-nilai yang hidup dan diyakini kebenarannnya oleh bangsa Indonsia (Maerani, 2015).

Hukum Pidana harus mencerminkan nilai-nilai budaya suatu bangsa dimana hukum tersebut berlaku. Sebagaimana dikemukakan oleh Sudarto (1983), bahwa hukum pidana itu seharusnya merupakan pencerminan dari nilai-nilai budaya yang hidup dalam masyarakat yang bersangkutan. Hukum pidana sebagai sistem sanksi yang negatif memberi sanksi terhadap perbuatan-perbuatan yang tidak dikehendaki oleh masyarakat itu. Hal ini berhubungan dengan pandangan hidup tata susila dan moral keagamaan serta kepentingan bangsa yang bersangkutan.

Pembangunan hukum nasional secara umum bermuara pada terwujudnya kesejahteraan dan perlindungan masyarakat. Demikian juga halnya pembangunan hukum pidana nasional bertujuan menciptakan ketertiban masyarakat untuk mewujudkan masyarakat sejahtera yang berkeadilan. Oleh sebab itu, dalam pembangunan hukum pidana nasional 
diperlukan adanya arah, dasar serta pendekatan yang digunakan agar tujuan pembangunan hukum pidana nasional tersebut dapat terwujud.

Pada saat ini pembangunan hukum pidana nasional yang mendesak dilakukan adalah pembentukan Kitab Undang-Undang Hukum Pidana (KUHP), karena merupakan sumber hukum pidana, akan tetapi samapai saat ini RUU-KUHP belum ditetapkan menjadi undang-undang. Keberadaan RUU-KUHP memunculkan pro dan kontra, oleh sebab itu untuk dapat memahami apakah RUU-KUHP yang sudah di tangan DPR apakah nantinya dapat mewujudkan kesejahteraan dalam masyarakat dan dapat menciptakan keadilan substantive dapat dilihat bagaimana politik hukum serta pendekatan hukum yang digunakan dalam penyusunan RUU-KUHP.

Bertolak pada teori Struktural Fungsional dari Talcott Parsons, melihat perkembangan ditataran praksis tersebut maka dapat dicermati dan dikaji bahwa ada kekuatan sub sitem ekonomi dan sub sistem politik yang berpengaruh dalam pembangunan hukum pidana Indonesia. Berdasarkan pada hasil penelitian, sub sistem ekonomi yang paling berpengaruh terhadap pembangunan hukum pidana Indonesia adalah modernisasi dan pembangunan. Hal ini dapat dilihat dari sikap pemerintah untuk mengkaji kembali Rancangan Undang-Undang KUHP akibat penolakan beberapa pihak yang mengatasnamakan pembangunan dan hak asasi manusia.

Sudah banyak penelitian maupun artikel yang membahas tentang pembentukan KUHP Baru, antara lain artikel yang ditulis oleh Nunung Nugroho dengan judul "Urgensi Pembaruan Kitab Undang-undang Hukum Pidana dalam Dinamika Masyarakat Indonesia" yang dimuat dalam jurnal Spektrum Hukum Vol.14 Nomor 1/April 2017. Artikel ini membahas tentang beberapa delik baru yang diatur dalam RUU-KUHP (Nugroho, 2019). Penelitian yang dilakukan oleh Nyoman Mahadhita Putra dan I Wayan Sutra Djaya yang berjudul "Pertanggungjawaban Pidana Pelaku Perbuatan Sumbang (Incest) dalam Konsep Kitab Undangundang Hukum Pidana (KUHP Baru)" yang dimuat dalam Kertha Wicara : Jurnal Ilmu Hukum 2013, membahas tentang kriminalisasi inses dengan dibentuknya ketentuan baru mengenai hal ini. Perubahan tersebut mengakibatkan perubahan pula dalam menentukan pertanggungjawaban pidana bagi pelakunya (Putra \& Djaya, 2013). Sedangkan penelitian yang dilakukan I Wayan David, Max Sepang dan Roy R. Lembong mengkaji tentang "Kedudukan Pidana Seumur Hidup Dalam Kerangka Pembentukan Hukum Pidana Nasional" yang dimuat dalam Jurnal Lex Crimen Vol. X/No. 4/Apr/EK/2021 mengkaji tentang bagaimana formulasi pidana seumur hidup dalam sistem hukum nasional.

Ketiga kajian penelitian di atas dapat dikatakan memiliki persamaan dengan tulisan artikel ini yaitu sama-sama mengkaji 
berhubungan dengan pembangunan hukum pidana nasional. Namun demikian, terdapat perbedaan yaitu penelitian ini lebih menfokuskan pada kajian tentang bagaimana politik hukum dalam pembangunan hukum pidana di Indonesia khususnya kaitanya dalam pembentukan KUHP baru dan pendekatan pembangunan hukum pidana dalam mewujudkan keadilan substantif. Oleh karena itu, penelitian ini bertujuan untuk mendiskripsikan dan menjelaskan politik hukum dalam pembangunan hukum pidana di Indonesia dan pendekatan pembangunan hukum pidana dalam mewujudkan keadilan substantif.

\section{METODE PENELITIAN}

Penelitian ini menggunakan metode pendekatan yang bersifat yuridis normatif, yaitu dengan mengkaji/menganalisis data sekunder yang berupa bahan-bahan hukum terutama bahan hukum primer dan bahan hukum sekunder (Soemitro, 1983: 24). Spesifikasi dalam penelitian ini adalah penelitian deskriptif analitis. Jenis dan teknik pengumpulan data dalam penelitian hukum diperoleh melalui studi kepustakaan. Dalam mendapatkan data menggunakan pendekatan historis, filosofis dan hermeneutik. Metode analisis data yang digunakan dalam penelitian ini adalah analisis kualitatif.

\section{PEMBAHASAN}

\section{Poltik Hukum dalam Pembangunan Hukum Pidana di Indonesia}

Menurut Paton (1951), pembangunan hukum pada hakikatnya teridiri dari dua hal, yaitu pembinaan hukum dan pembaharuan hukum. Pembaharuan hukum ialah membentuk tatanan hukum yang baru kembali. Sedangkan pembinaan hukum ialah perawatan hukum yang telah ada, jadi bukan menghancurkan, memanjakan, dan membiarkannya tumbuh sesukanya (Nur, 1985: 195).

Barda Nawawi Arief menjelaskan pembangunan hukum pidana pada hakikatnya mengandung makna suatu upaya untuk melakukan reorientasi dan reformasi hukum pidana yang sesuai dengan nilai-nilai sentral sosio-politik, sosio-filosofis, dan sosio-kultural masyarakat Indonesia yang melandasi kebijakan sosial, kebijakan kriminal dan kebijakan penegakan hukum di Indonesia (Arif, 2008: 25). Berdasarkan pendapat Barda Nawawi Arief tersebut dapat dikatakan bahwa untuk mendapatkan hukum yang dapat mewujudkan rasa keadilan dan membawa kemanfaatan bagi masyarakat, dalam melakukan pembangunan/pembaharuan hukum tidak boleh lepas dari politik hukum, perkembangan sosial masyarakat dan harus berdasar pada budaya bangsa.

Pembangunan hukum pidana bukan sekedar memperbaharui/mengganti rumusan pasal-pasal secara tekstual, akan 
tetapi hakikat pembaharuan hukum pidana adalah membangun/memperbaharui pokok-pokok pemikiran/konsep/ide dasarnya (Arif, 2005: 1). Pembangunan hukum pidana sesungguhnya adalah kebijakan untuk memperbaharui substansi hukum agar hukum dapat ditegakkan secara efektif. Hukum yang dapat ditegakkan secara efektif adalah hukum yang sesuai dengan jiwa bangsa yang bersangkutan. Oleh karena itu pembaharuan substansi hukum harus berdasar pada jiwa bangsa.

Dalam pembangunan hukum, politik hukum menjadi bagian yang sangat penting dalam prosesnya. Adapun tujuan politik hukum tersebut adalah agar terbentuk hukum nasional lebih sesuai dengan jiwa bangsa Indonesia, sehingga akan dapat mewujudkan keadilan yang dicita-citakan bangsa Indonesia. Dikemukakan oleh Satjipto Rahardjo (2008) bahwa acuan utama tata hukum adalah Pancasila dan Undang-Undang Dasar Negara Republik Indonesia Tahun 1945. Berkaitan dengan hal tersebut maka dalam pembangunan hukum pidana nasional harus mampu mendayagunakan sila-sila Pancasila sebagai landasan filosofi. Oleh sebab itu dalam melakukan pembangunan hukum pidana nasional harus diperhatikan hal-hal sebagai berikut (Sutrisna, 2009: 103-104):

1) Tidak boleh bertentangan dengan prinsip-prinsip Ketuhanan Yang Maha Esa yang menghormati ketertiban hidup beragama, rasa keagamaan dan agama sebagai kepentingan yang besar.

2) Menghormati nilai-nilai Hak Asasi Manusia baik hak-hak sipil dan politik maupun hak-hak ekonomi, sosial dan budaya dan dalam kerangka hubungan antar bangsa harus menghormati "the right to development"

3) Harus mendasarkan persatuan nasional pada penghargaan terhadap konsep "civic nationalism" yang mengapresiasi pluralisme.

4) Harus menghormati indeks atau "core values of democrary" dan

5) Harus menempatkan "legal justice" dalam kerangka "social justice" dan dalam hubungan antar bangsa berupa prinsip-prinsip "global justice".

Melihat kisi-kisi tersebut maka pembangunan hukum nasional harus dapat mewujudkan cita dan tujuan bangsa, sebagaimana yang tercantum dalam Pembukaan UUD NRI Tahun 1945. Pembangunan hukum nasional bukan hanya untuk kepentingan segelintir atau sekelompok orang yang bersifat temporal. Dalam upaya meminimalisir kemungkinan pembangunan hukum nasional yang bersifat pragmatis dengan mengabaikan cita-cita luhur bangsa Indonesia, maka hukum dan sistem hukum nasional tidak boleh menafikkan nilai-nilai luhur bangsa Indonesia yang sudah terkristalisasi dalam sila-sila Pancasila.

Pelaksanaan pembangunan hukum pidana nasional tidak dapat menafikkan urgensi politik hukum. Menurut Moh. Mahfud MD bahwa politik hukum mencakup proses pembuatan dan pelaksanaan hukum 
yang dapat menunjukkan sifat dan ke arah mana hukum akan dibangun dan ditegakkan (MD, 2006: 1). Oleh sebab itu, berbicara tentang pembangunan hukum tidak dapat dilepaskan dari politik hukum. Demikian pula halnya dalam melakukan pembangunan hukum pidana nasional tidak dapat lepas dari politik hukum (Sudarto, 1983: 20), karena politik hukum merupakan penentu arah kemana hendaknya hukum ini dibangun.Terkait dengan hal tersebut, maka menjadi keniscayaan bahwa dalam melakukan pembangunan hukum nasional yang dalam hal ini adalah hukum pidana, harus berdasarkan pada politik hukum nasional.

Dikemukakan pula oleh Moh. Mahfud MD, jika hukum diartikan sebagai alat untuk meraih cita-cita dan mencapai tujuan, maka politik hukum diartikan sebagai arah yang harus ditempuh dalam pembuatan dan penegakan hukum guna mencapai cita-cita dan tujuan bangsa. Dengan kata lain politik hukum adalah upaya menjadikan hukum sebagai proses pencapaian cita dan tujuan (MD, 2006: 31). Mendasarkan pada pendapat Mahfud MD tersebut, dapat dikatakan bahwa politik hukum menjadi acuan pemikiran pada tahap pembentukan hukum (law inabstracto) dan tahap penegakan hukum (law in-concreto).

Sunaryati Hartono menjelaskan politik hukum merupakan alat atau sebagai sarana dan langkah yang dapat digunakan pemerintah untuk menciptakan sistem hukum nasional dalam upaya mencapai cita-cita bangsa (Hartono, 1991: 1). Adapun Sudarto (1983) berpendapat bahwa politik hukum adalah usaha untuk mewujudkan peraturan-peraturan yang baik sesuai dengan keadaan dan situasi pada suatu waktu. Ditambahkan oleh Sudarto bahwa politik hukum adalah suatu kebijakan dari negara melalui badan-badan yang berwenang untuk menetapkan peraturan yang dikehendaki yang diperkirakan bisa digunakan untuk mengekspresikan apa yang terkandung dalam masyarakat dan untuk mencapai apa yang dicita-citakan. Mengacu pada beberapa pendapat tersebut dapat ditarik benang merah bahwa politik hukum adalah suatu acuan dalam melakukan pembangunan hukum dengan berdasar pada nilai-nilai yang terkandung dalam masyarakat, agar tercipta suatu hukum yang dapat mewujudkan cita-cita bangsa sebagaimana yang terangkum dalam tujuan nasional.

Berdasarkan pada pengertian politik hukum tersebut, maka dapat dijelaskan bahwa politik hukum merupakan sebuah kekuatan dan strategi yang dapat mewarnai atau membentuk suatu hukum dan juga kekuatan yang mengarahkan bagaimana hukum harus ditegakkan dalam rangka mencapai tujuan nasional. Satu hal yang harus tetap dijunjung tinggi adalah bahwa tujuan akhir dari politik hukum adalah mencapai cita-cita bangsa, oleh sebab itu pembaharuan hukum harus dapat mengakomodasi kehendak dan kepentingan rakyat serta dapat mewujudkan cita-cita yang dikehendaki rakyat. 
Bertolak pada pengertian politik hukum, pada dasarnya hukum adalah alat untuk mencapai tujuan negara, maka dapat dikatakan bahwa keberadaan hukum merupakan suatu bentuk produk politik yang merupakan alat pemerintah dalam upaya mewujudkan tujuan dari kebijakannya. Sebagaimana yang dikemukakan oleh T.M. Radhie mantan kepala BPHN bahwa politik hukum sebagai suatu pernyataan kehendak penguasa negara mengenai hukum yang berlaku di wilayahnya dan mengenai arah pembangunan hukum yang dibangun.Berdasar pada definisi tersebut, maka dapat diketahui bahwa kekuatan yang menentukan isi, bentuk maupun bagaimana hukum ditegakkan, baik terhadap hukum yang saat ini sedang berlaku, maupun pada hukum yang akan datang adalah penguasa negara.

Dalam salah satu pilar grand design Sistem dan Politik Hukum Nasional disebutkan bahwa produk hukum harus merupakan hukum yang konsisten dengan Falsafah negara, mengalir dari landasan konstitusi UUD NRI Tahun 1945 dan secara sosiologis menjadi sarana untuk terciptanya keadilan dan ketertiban masyarakat (Jaya, 2014: 22). Artinya, bagaimanapun politik hukum yang mewarnai pembentukan suatu hukum, yang penting tujuan akhir pembentukan hukum adalah terwujudnya keadilan dan kesejahteraan masyarakat.

Sebagaimana yang dikemukakan oleh Suteki dengan mengutip pendapat Moh. Mahfud MD, bahwa Pancasila dapat memandu politik hukum nasional dalam berbagai bidang, dengan rincian sebagai berikut (Suteki, 2010: 67-68):

1) Sila Ketuhanan Yang maha Esa menjadi landasan politik hukum yang berbasis moral agama;

2) Sila Kemanusiaan yang adil dan beradab menjadi landasan politik hukum yang menghargai dan melindungi hak-hak asasi manusia yang non diskriminatif;

3) Sila Persatuan Indonesia menjadi landasan politik hukum untuk mempersatukan seluruh unsur bangsa dengan berbagai ikatan primordialnya masing-masing;

4) Sila Kerakyatan yang dipimpin oleh hikmat kebijaksanaan dalam permusyawaratan perwakilan menjadi landasan politik hukum yang meletakkan kekuasaan di bawah kekuasaan rakyat (demokratis);

5) Sila Keadilan sosial bagi seluruh rakyat Indonesia menjadi landasan politik hukum dalam hidup bermasyarakat yang berkeadilan sosial sehingga mereka yang lemah secara sosial dan ekonomis tidak ditindas oleh mereka yang kuat secara sewenang-wenang.

Menurut Benard L.Tanya (Prasetyo \& Tanya, 2011: 5), politik hukum adalah persoalan pencapai tujuan. Ada beberapa tujuan yang diembankan pada hukum. Masih menurut Benard L.Tanya, bahwa dalam memadu arah politik hukum (pidana) di Indonersia terdapat sedikitnya 
empat prinsip yang disepakati oleh para sarjana sebagai cita hukum Indonesia, yaitu :

1) Perlindungan terhadap semua unsur nation demi integrasi bangsa.

2) Perwujudan keadilan sosial dalam bidang ekonomi dan kemasyarakatan.

3) Mewujudkan demokrasi dan 'nomokrasi' dalam hidup bernegara. Nomos (hukum) menjadi "penguasa atas penguasa".

4) Menciptakan toleransi atas dasar kemanusiaan dan keadaban dalam hidup beragama.

Keempat prinsip tersebut merupakan cita hukum, yang harus menjadi asas dan pedoman dalam setiap pembangunan hukum di Indonesia, karena dengan cita hukum inilah tujuan pembangunan hukum, termasuk di dalamnya tujuan hukum, akan dapat terwujud. Sebagaimana yang dikemukakan oleh Gustav Radbruch bahwa tujuan pembangunan hukum adalah untuk menciptakan kepastian hukum, mengutamakan asas kemanfaatn dan mewujudkan keadilan.Memahami bahwa hukum sebagai alat untuk mewujudkan tujuan kebijakan pemerintah, maka yang harus diperhatikan untuk dilaksanakan adalah tujuan akhir pembanguann hukum pidanaadalah mewujudkan kesejahteraan masyarakat.

Menurut Moh. Mahfud MD (2006), bertolak pada empat prinsip tersebut, masalah-masalah mendasar yang harus diperhatikan di dalam politik hukum nasional, yaitu :

1) Hukum harus memelihara integrasi bangsa baik secara ideologi maupun secara teritorial;

2) Hukum harus membuka jalan bahkan menjamin terciptanya keadilan sosial bagi seluruh masyarakat Indonesia;

3) Hukum harus menjamin tampilnya tata politik dan kenegaraan yang demokratis dan nomokratis;

4) Hukum harus mampu membangun terciptanya toleransi hidup bersama di antara para warganya dan menjamin agar tak seorangpun melanggar atau dilanggar haknya dalam memeluk dan melaksanakan ajaran agama yang diyakini dan dianut.

Menilik hakikat politik hukum nasional yang merupakan kebijakan dasar untuk menentukan arah, bentuk, maupun isi dari hukum yang akan dibentuk, maka peran politik hukum menjadi sangat menentukan untuk dapat menciptakan unifikasi hukum yang dapat mempersatukan bangsa, menciptakan keadilan sosial bagi masyarakat, menciptakan hukum yang mengakomodir keinginan dan kebutuhan rakyat serta harus dapat menciptakan hukum yang menghargai keberadaan agama dan umat beragama. Apabila keempat prinsip dapat terakomodir dalam pembaharuan hukum pidana nasional maka hukum yang baru tersebut akan sesuai dengan cita-cita dan tujuan nasional bangsa Indonesia. 
Berdasar pada empat prinsip tersebut maka dalam melakukan pembaharuan hukum pidana hal-hal yang harus diperhatikan, pertama dalam pembaharuan hukum jangan sampai menimbulkan perpecahan bangsa, oleh sebab harus dapat mengakomodasi kepentingan semua elemen. Kedua, dalam pembaharuan hukum harus dapat mewujudkan keadilan di masyarakat dalam bidang apapun. Keadilan yang dimaksud di sini bukan keadilan prosedural tetapi keadilan substantif. Ketiga, pembaharuan hukum harus dapat mengarahkan negara untuk dapat mewujudkan kesejahteraan bangsa, dan memenuhi kepentingan rakyat sebagai pemegang kedaulatan dalam suatu negara. Keempat, dalam pembaharuan hukum nasional harus dapat mmenciptakan iklim kehidupan beragama, berbudaya yang berkeadaban dan saling menghargai, menghormati.

Perlu untuk difahami bahwa undang-undang adalah suatu produkpolitik, yang kerenanya sangat diwarnai oleh berbagai kepentingan, khususnyakepentingan dari aktor pembuatnya, yaitu Dewan Perwakilan Rakyat (DPR) dan Presiden, dan juga kekuatan-kekuatan lainnya yang dimiliki oleh Negara atau di luar itu, seperti kekuatanketuatan sosial, politik, ekonomi, dan lain-lain. Undang-undang (kebijakan legislatif) harus dipandang sebagai suatu siteof struggle antara kekuatan-kekuatan itu.Ia sama sekali tidak berada di ruanghampa (Prasetyo \& Tanya, 2011: 6-9).

Sebagaimana halnya dalam pembentukan KUHP Baru, nuansa kekuatan politik dan ekonomi sangat kentara. Hal ini dapat diketahui dengan belum ditetapkannya RUU-KUHP menjadi undang-undang meskipun sudah ditangan DPR sejak tahun 2019. Tarik ulur serta pro kontra terhadap pasal-pasal yang ada dalam RUU-KUHP menunjukkan pengaruh kuasa sosial, politik dan ekonomi sangat kuat.

Sebagaimana diungkapkan di muka bahwa politik hukum nasional tertuang dalam Undang-undang Dasar Negara Republik Indonesia Tahun 1945. Di dalam Undang-undang Dasar Negara Republik Indonesia Tahun 1945 tercantum tujuan nasional bangsa Indonesia yang berdasarkan silasila Pancasila, yaitu melindungi segenap bangsa Indonesia dan seluruh tumpah darah Indonesia (Maerani, 2015: 26). Pancasila sebagai dasar negara yang merupakan ideologi, dasar falsafah dan sumber segala sumber hukum bangsa Indonesia. Oleh sebab itu menjadi keharusan bahwa landasan yang digunakan dalam politik hukum untuk membangun hukum pidana yang dalam hal ini adalah membentuk KUHP Baru adalah Pancasila dan UUD NRI Tahun 1945 (Sudarto, 1983: 20). 


\section{Pendekatan Pembangunan Hukum Pidana dalam Mewujudkan Keadilan Substantif}

Diuraikan di muka bahwa keadilan yang hendak dicapai dalam pembangunan hukum nasional adalah keadilan substantif bagi masyarakat bukan keadilan formal. Oleh karena itu, pembangunan hukum nasional harus dapat mengakomodasi keberadaan hukum agama dan hukum adat sebagai hukum yang hidup dalam masyarakat, yang selama ini menurut masyarakat Indonesia dirasa lebih dapat mewujudkan keadilan yang sesungguhnya.

Arti penting keberadaan hukum agama dan hukum adat dalam pembangunan hukum nasional dikemukakan oleh Menski (2006) dengan teori triangular concept of legal pluralism, atau yang dikenal dengan pluralisme hukum yaitu persentuhan antara hukum positif dengan "living law" yang berupa hukum hukum adat, hukum agama, maupun hukum kebiasaan dalam suatu masyarakat.

Masyarakat Indonesia merupakan masyarakat yang religius, maka seharusnya dalam melakukan pembaharuan hukum pidana nasional digunakan pendekatan religius dan pendekatan keilmuan sebagaimana yang sejalan dengan pendekatan legal pluralism, bahwa dalam melakukan pembaharuan hukum harus mendasarkan pada moral (religion), hukum negara dan kebiasaan. Berkaitan dengan hal tersebut,maka pendekatan yang digunakan dalam pembaharuan hukum pidana tersebut sangat urgent, karena menjadi dasar penentuan politik pembangunan hukum nasional.

Menurut Barda Nawawi Arief bahwa dalam melakukan pembaharuan hukum harus menggunakan pendekatan humanis, pendekatan kultural, dan pendekatan religius, yang kemudian diintegrasikan ke dalam pendekatan nasional yang berorientasi pada kebijakan, sejalan dengan yang dikemukakan oleh Werner Menski tentang legal pluralism, yaitu bahwa dalam mewujudkan keadilan substantif yang menurutnya sebagai Perfect justice harus mengintegrasikan keseimbangan elemen-elemen state positivism, society/socio-legal approach dan religion/morality/ethics (Arif, 2005: 9).

Efektivitas penegakan hukum pidana sangat penting dipikirkan dalam pembangunan hukum pidana karena misi dalam pembangunan hukum pidana adalah upaya rasional untuk memberantas atau menanggulangi tindak pidana dalam rangka untuk mewujudkan perlindungan masyarakat dan dalam mencapai tujuan nasional. Oleh karena itu, untuk mencapai tujuan dari pembangunan hukum pidana tersebut, pembanguan hukum pidana harus berdasar pada pokok-pokok pemikiran, ide-ide dasar, atau nilai-nilai sosio-filosofik, sosio-politik, dan sosio-kultural bangsa Indonesia (Arif, 2005: 3). 
Terkait dengan pendekatan nilai yang melandasi politik hukum dalam pembangunan hukum pidana Indonesia, seharusnya mengangkat nilai-nilai religius dan nilai-nilai adat sebagai basic idea. Sebagaimana pendapat Suteki (2013) bahwa pelembagaan kembali (reinstitutionalization) asas-asas atau kebiasaan-kebiasaan ke dalam produk hukum nasional merupakan pengakuan akan eksistensi hukum adat maupun hukum agama. Perlunya pelembagaan hukum adat dan hukum agama adalah karena nilai-nilai adat dan nilai-nilai religius sudah mendarah daging dalam masyarakat, yang menurut masyarakat mengandung kepatutan, keadilan, kepastian, dan diyakini apabila tidak dipatuhi/tidak dijalankan akan ada akibat, baik yang nyata maupun tidak nyata karena kebiasaan yang ada di dalamnya telah menjadi kesadaran jiwa yang mendalam.

Adapun maksud pembangunan hukum pidana dilakukan dengan pendekatan nilai (value approach) adalah suatu pendekatan dengan mengkaji dan selanjutnya mendasarkan pada nilai-nilai yang berlaku dalam masyarakat sekarang, tentang apa yang tercela, yang tidak patut dalam pandangan masyarakat sehingga seharusnya dijatuhi pidana. Oleh sebab itu Pancasila harus dijadikan sebagai acuan paradigmanya maupun kerangka berpikirdalam pembangunan hukum pidana Indonesia.Hal ini karena Pancasila adalah kristalisasi nilai-nilai luhur bangsa Indonesia yang diyakini kebenarannya.Berdasarkan hal tersebut Pancasila harus dijadikan orientasi arah, sumber nilai-nilai serta menjadi kerangka berpikir dalam setiap upaya pembangunan hukum pidana agar dapat mewujudkan keadilan substantive dalam masyarakat.

Dalam upaya menciptakan hukum yang sesuai dengan masyarakat dari suatu bangsa, maka hukum harus dapat mengadopsi nilai-nilai keadilan, ukuran kesejahteraan, serta kepentingan yang secara umum dibutuhkan masyarakat tersebut. Oleh sebab itu dikemukakan oleh Satjipto Rahardjo, bahwa dalam melakukan pembaharuan hukumharus memperhatikan lingkungan karena sesungguhnya hukum itu tidak bebas nilai.Demikian pula yang dikemukakan Capra (2001) dengan teori Deep Ecology, bahwa dalam membuat hukum harus memperhatikan segala sesuatu yang terkait, tidak boleh meminggirkan hal-hal yang memang seharusnya dipertimbangkan dalam pembuatan hukum. Nilai-nilai, keyakinan yang ada dalam masyarakat, struktur masyarakat, kemauan penguasa, kekuatan gaib maupun kondisi alamiah lingkungan suatu masyarakat merupakan bagian yang tidak boleh diabaikan sebagai dasar pemikiran dan pertimbangan dalam pembentukan hukum.

Dalam pembangunan hukum, selain kondisi lingkungan sekitar yang harus diperhatikan, perlu kiranya diperhatikan pula sub sistem-sub sistem yang ada di dalam masyarakat. Hal tersebut dikarena ada sub sistem yang menjadi faktor pendukung terbentuknya suatu hukum tetapi 
ada pula sub sistem yang menjadi faktor penghambat terbentuknya hukum.

Talcott Parsons menjelaskan bahwa di dalam masyarakat terdiri dari sub-sub sistem yang saling berhubungan dan saling mempengaruhi. Hubungan antar sub sistem tersebut melalui arus informasi dan arus energi. Hukum berada dalam sub sistem budaya atau sosial yang mempunyai arus informasi tinggi, akan tetapi energi yang dimiliki paling rendah diantara sub sistem yang lain sehingga keberadaan hukum dipengaruhi oleh sub-sub sistem lain yang lebih tinggi, yaitu sub sistem politik dan ekonomi. Hal tersebut menunjukkan dalam pembuatan suatu peraturan, faktor ekonomi dan politik mengemudikan arah kebijakan pembuat peraturan. Dengan kata lain energi sub sistem ekonomi dan politik yang besar mempengaruhi pembentukan/pembaharuan hukum.

Sedangkan menurut Gustav Radbruch Dalam melakukan pembaharuan suatu peraturan harus berdasar pada cita hukum (rechtsidee). Menurut beliau cita hukum yang dikehendaki masyarakat meliputi tiga hal yaitu kepastian, kemanfaatan dan keadilan (Huijbers, 1982: 162). Oleh sebab itu dalam memperbaharui suatu peraturan, ketiga hal tersebut harus menjadi dasar pertimbangan yang utama bagi para pembentuk hukum/peraturan. Dalam mewujudkan cita hukum dari Gustav Radbruch tersebut harus dilakukan dengan memperhatikan keseimbangan antara kepastian hukum, kemanfaatan hukum dan keadilan, agar keadilan substantif yang hendak diwujudkan dalam pembaharuan hukum dapat tercapai.

Menurut Menski, bahwa dalam mewujudkan keadilan substantif yang menurutnya sebagai perfect justice harus mengintegrasikan keseimbangan elemen-elemen state positivism, society/socio-legal approach dan religion/morality/ethics (Arif, 2005: 9). Berdasarkan pada pendapat Menski tersebut maka dalam melakukan pembangunan hukum pidana nasional tidak dapat hanya menggunakan satu pendekatan saja, misalnya dengan pendekatan positivism yang memandang hukum adalah undangundang, di luar undang-undang bukan hukum. Pendekatan ini menafikkan keberadaan hukum-hukum lain, yang lebih dapat memenuhi rasa keadilan masyarakat.

Pembangunan hukum pidana nasional juga tidak dapat mengikuti aliran hukum murni, yang mengatakan bahwa hukum bebas nilai, karena sesungguhnya dalam pembentukan hukum sarat diwarnai oleh nilai-nilai dan kepentingan-kepentingan. Sebagaimana pendapat Pospisil yang mengatakan bahwa sesungguhnya hukum adalah hasil interaksi sosial yang dipengaruhi oleh aspek-aspek kebudayaan, politik, ekonomi, sosial, religi dan lain-lain (Putra \& Djaya, 2013: 63).

Melihat negara Indonesia yang multi kultur, maka menggunakan pendekatan legal pluralism dirasa lebih tepat dalam pembangunan hukum 
nasional. Pembangunan hukum hendaknya merespon, mengakomodir dam selanjutnya mengintegrasikan nilai-nilai dari hukum adat, hukum agama, dan nilai-nilai lain yang hidup dalam masyarakat yang masih berlaku dan memberikan keadilan pada masyarakat kedalam suatu regulasi atau hukum negara yang menghasilkan sistem hukum nasional yang dapat mewujudkan keadilan substantif.

Menurut Werner Menski, dengan Triangular Concept of Legal Pluralism, bahwa untuk mendapatkan hukum yang dapat menciptakan perfect justice digunakan ketiga sumber hukum, yang di sini digambarkan tiga sudut dalam satu segitiga, yaitu sudut sumber hukum agama/moral (religion law/morality), sudut hukum negara (state law), sudut hukum adat (living law).

Menurut Satjipto Rahardjo (2008), yang mengistilahkan pembaharuan hukum nasional dengan merombak dan membangun hukum Indonesia bahwa pembaharuan hukum nasional harus sesuai dengan jiwa bangsa (volkgeist) Indonesia, yang merupakan perpaduan antara pendekatan yang berorientasi pada nilai,pendekatan humanis, pendekatan kultural, dan pendekatan religius yang dintegrasikan kedalam pendekatan rasional yang berorientasi pada kebijakan (policy oriented approach). Hal tersebut karena sesungguhnya jiwa bangsa khususnya bangsa Indonesia dibentuk, diwarnai dan dikendalikan oleh norma-morma agama, budaya, perilaku yang memanusiakan manusia.

Dalam melakukan pembanguan hukum pidana harus sesuai dengan jiwa bangsa, karena hukum/peraturan merupakan endapan dari nilai-nilai atau norma-norma yang hidup dalam masyarakat dan umum diterima oleh masyarakat, tertuang dalam bentuk rangkaian aturan-aturan hukum itu sebagaimana yang dikemukakan oleh Roeslan Saleh (1984). Sedangkan Soekarno Presiden Republik Indonesia pertama mengemukakan yang dibahasakan oleh Moeljatno "bahwa hukum adalah tidak lain daripada ekspresi cita-cita politik rakyat". Senada dengan yang dikemukakan oleh Roeslan Saleh dan Sudarto adalah teori dari Eugen Ehrlich dan Tamanaha.

Eugen Ehrlich (2009) mengatakan bahwa hukum seharusnya bersumber pada nilai-nilai yang hidup. Hukum selalu berakar pada suatu komunitas sosial-kultural tertentu. Hukum selalu berakar pada suatu "peculliar form of social life" (Rahardjo, 2008: 105). Teori Mirror Thesis dari Tamanaha mengatakan "Every Legal systems and in a close relationship to the ideas, aim and purpose of society. Law reflects the intelektual, social, economic, and political climate of its time". Dari beberapa pendapat tersebut dapat ditarik benang merah bahwa pada dasarnya hukum merupakan pencerminan nilai-nilai sosial, nilai-nilai moral, dan tujuan hidup masyarakat yang bersangkutan. Hukum yang dapat dilaksanakan adalah hukum yang sesuai dengan jiwa dan kepribadian bangsa yang 
bersangkutan. Oleh sebab itu pembaharuan hukum pidana harus berdasarkan jiwa bangsa agar hukum yang ada dapat berlaku efektif.

Lebih jauh dan lebih dalam Barda Nawawi Arief (2005) mengemukakan tentang arti penting hukum adat dan hukum agama untuk dijadikan dasar dalam melakukan pembaharuan hukum pidana. Dikemukakan oleh beliau bahwa pembaharuan hukum pidana harus dilakukan dengan menggunakan pendekatan yang berorientasi pada kebijakan (policy oriented approach) dan juga menggunakan pendekatan yang berorientasi pada nilai (value oriented approach).

Nilai di sini meliputi nilai-nilai kemanusiaan (pendekatan humanis), nilai-nilai identitas budaya (pendekatan kultural), dan nilainilai moral keagamaan (pendekatan religious). Artinya, di samping nilainilai budaya, adat istiadat, moral keagamaan sebagai dasar dan jiwa dalam pembangunan hukum nasional, tidak boleh ditinggalkan pula kebijakan-kebijakan pemerintah yang merupakan pengintegrasian dari nilai-nilai tersebut yang telah dituangkan dalam suatu peraturan sebagai dasar hukum dalam pelaksanaan pembangunan hukum nasional. Menurut Barda Nawawi Arief pendekatan tersebut dilakukan karena lebih dekat dengan karakteristik masyarakat Indonesia yang bersifat monodualistik dan pluralistik. Oleh sebab itu perlu dilakukan kajian perbandingan dari sudut keluarga hukum tradisional dan agama (traditional an religious law family) (Arif, 2011: 8).

Menurut Barda Nawawi Arief, himbauan untuk melakukan "pendekatan yang berorientasi pada nilai" (value oriented approach), baik nilai-nilai kemanusiaan maupun nilai-nilai identitas budaya dan nilai-nilai moral keagamaan, merupakan himbauan untuk melakukan "pendekatan humanis", "pendekatan kultural" dan "pendekatan religius" yang diintegrasikan ke dalam pendekatan rasional yang berorientasi pada kebijakan (policy-oriented approach) (Arif, 2008: 327). Himbauan tersebut ditangkap dan diimplementasikan oleh pembuat kebijakan dalam melakukan pembangunan hukum pidana nasional.

Wujud kebijakan pemerintah yang merupakan pengintegrasian dari nilai-nilai adat, kebudayaan dan agama sebagi dasar dalam pembangunan hukum nasional secara jelas dapat dilihat dalam GBHN hasil Sidang Umum Kabinet Persatuan Nasional tahun 1999 yang dituangkan dalam Bab IV huruf A butir 2, yaitu disebutkan : "Menata sistem hukum nasional yang menyeluruh dan terpadu dengan mengakui dan menghormati hukum agama dan hukum adat ...". GBHN merupakan pedoman pembangunan nasional termasuk didalamnya pembangunan hukum, oleh sebab itu menggunakan GBHN sebagai landasan pembangunan hukum nasional merupakan salah satu bentuk penggunaan pendekatan rasional yang berorientasi pada kebijakan (policyoriented approach) dalam pembangunan hukum nasional. 
Di samping tertuang dalam GBHN, dipakainya pendekatan rasional yang berorientasi pada kebijakan (policy-oriented approach) dalam pembangunan hukum nasional dapat dilihat dalam berbagai seminar hukum nasional, dengan dicapainya kesepakatan bahwa dalam melakukan pembaharuan hukum nasional harus menggunakan pendekatan kultural dan religius. Bahkan dalam seminar nasional ke-8 Tahun 2003 ditegaskan agar nilai-nilai religius dijadikan sebagai sumber motivasi, inspirasi, muatan substantif dan sumber evaluasi (Arif, 2011: 7).

Mencermati berbagai kebijakan, baik dari pemerintah maupun hasil kesepakatan pada forum-forum ilmiah, menunjukkan bahwa untuk bangsa dan negara Indonesia yang multi kultural, dalam pembangunan hukum nasional akan lebih dapat menghasilkan hukum yang nantinya menciptakan keadilan substantif atau perfect justice apabila digunakan pendekatan rasional yang berorientasi pada kebijakan (policy-oriented approach), sebagaimana halnya pendekatan legal pluralism yang mengintegrasikan keseimbangan elemen-elemen state positivism, society/socio-legal approach dan religion/morality/ethics.

Demikian pula halnya dalam pembangunan hukum pidana khususnya dalam pembentukan KUHP Baru sebagai sumber hukum pidana di Indonesia, penggunaan pendekatan religious, pendekatan ilmu, pendekatan humanis, pendekan kebijakan akan dapat mewujudkan KUHP yang dapat menjadi sumber hukum pidana dan sekaligus sebagai hukum yang dapat mewujudkan kesejahteraan dan menciptakan keadilan substantif sebagaimana yang diharapkan masyarakat luas.

\section{SIMPULAN}

Berdasarkan pembahasan di atas dapat disimpulkan bahwa Politik hukum adalah arah pembangunan hukum atau pembuatan dan pemilihan hukum yang berpijak pada kebijakan negara untuk membuat dan menetapkan peraturan perundang-undangan guna mencapai cita-cita dan tujuan negara sebagaimana yang terdapat dalam alinea IV Pembukaan UUD NRI 1945. Adapun dasar yang digunakan untuk menentukan arah pembangunan hukum tersebut adalah nilai-nilai yang hidup dalam masyarakat yang terkristalisasi dalam sila-sila Pancasila. Sedangkan pendekatan yang digunakan dalam pembangunan hukum agar dapat mengadopsi nilai-nilai yang hidup dalam masyarakat tersebut menggunakan pendekatan religius, pendekatan keilmuan, pendekatan kebijakan dan pendekatan humanis. 


\section{DAFTAR PUSTAKA}

\section{Buku-buku}

Arif, B. N. (2005). Pembaharuan Hukum Pidana Dalam Perspektif Kjian Perbandingan. Bandung: Citra Aditya Bakti.

Arif, B. N. (2008). Bunga Rampai Kebijakan Hukum Pidana (Perkembangan Penyusunan Konsep KUHP Baru). Jakarta: Kencana Prenada Media Group.

Arif, B. N. (2011a). Kapita Selekta Hukum Pidana. Bandung: Citra Aditya Bakti.

Arif, B. N. (2011b). Pornografi Pornoaksi dan Cybersex-Cyberporn Semarang: Pustaka Magister. Semarang: Pustaka Magister.

Capra, F. (2001). Jaring-jaring Kehidupan Visi Baru Epistemologi dan Kehidupan. Yogyakarta: Fajar Pustaka.

Ehrlich, E. (2009). Bunga Rampai Hukum dan Globalisasi. Yogyakarta: Genta Press.

Jaya, N. S. P. (2014). Politik Hukum. Semarang: Universitas Diponegoro.

MD, M. M. (2006). Membangun Politik Hukum Menegakkan Konstitusi. Jakarta: Pustaka LP3ES Indonesia.

MD, M. M. (2006). Politik Hukum di Indonesia. Jakarta: Rajawali Press.

Menski, W. (2006). Comparative Law in A Global Context, the legal system of Asia Afrika. Cambridge University Press.

Prasetyo, D. I., \& Tanya, B. L. (2011). Hukum Etika dan Kekuasaan. Yogyakarta: Gentha Publishing.

Rahardjo, S. (2008). Membangun dan Merombak Hukum Indonesia Sebuah Pendekatan Lintas Disiplin. Yogyakarta: Genta Press.

Saleh, R. (1984). Sisi Lain Hukum Pidana. Jakarta: Ghalia Indonesia.

Soemitro, R. H. (1983). Metodologi Penelitian Hukum. Jakarta: Ghalia Indonesia.

Suteki. (2010). Rekonstruksi Politik Hukum Hak Atas Air Pro-Rakyat. Semarang: Surya Pena Gemilang Publishing.

Suteki. (2013). Desain Hukum di Ruang Sosial. Semaarang: Thafa Media.

Sutrisna, E. (2009). Bunga Rampai Hukum dan Globalisasi. Yogyakarta: Genta Press. 


\section{Jurnal-jurnal}

Maerani, I. A. (2015). Implementasi Ide Keseimbangan Dalam Pembangunan Hukum Pidana Indonesia Berbasis Nilai-Nilai Pancasila. Jurnal Pembaharuan Hukum, 11(2), 329-338. http://jurnal.unissula.ac.id/index.php/PH/article/view/1364

Maulidah, K., \& Jaya, N. S. P. (2019). Kebijakan Formulasi Asas Permaafan Hakim dalam Upaya Pembaharuan Hukum Pidana Nasional. Jurnal Pembangunan Hukum Indonesia, 1(3), 281-293. https://doi.org/10.14710/jphi.v1i3.281-293

Nugroho, N. (2019). Urgensi Pembaruan Kitab Undang-Undang Hukum Pidana Dalam Dinamika Masyarakat Indonesia. Spektrum Hukum, 14(1), 39-57. https://doi.org/10.35973/sh.v14i1.1102

Nur, S. R. (1985). Membina Hukum Adat Menjadi Hukum Penghayatan Pancasil Dalam Bidang Hukum" Bunga Rampai Pembangunan Hukum Indonesia. Eresco.

Putra, N. M., \& Djaya, I. W. S. (2013). Pertanggungjawaban Pidana Terhadap Pelaku Perbuatan Sumbang (Incest) dalam Konsep Kitab Undang-Undang Hukum Pidana (HUKP) Baru. Journal Ilmu Hukum, $1-5$. 
Any Ismayawati

Halaman ini sengaja dikosongkan 